\title{
A IGREJA CATÓLICA: forma de governo e regime político
}

THE CATHOLIC CHURCH: form of government and political system

\section{Salmo Caetano de Souza ${ }^{1}$}

\begin{abstract}
Resumo:
O presente artigo objetiva explicar para os interessados no Direito Internacional a Forma de Governo e o Regime Político da Igreja Católica para, em seguida, poder entender que o que se afirma sobre esses dois aspectos da Igreja Católica afirma-se, também, sobre a Suprema Autoridade da Igreja Católica (o Papa) e a Santa Sé. Ao final, fica evidente que a Suprema Autoridade da Igreja Católica e a Santa Sé são duas expressões com o mesmo significado, vale dizer, expressam a mesma realidade, a saber, o Papa, ou em linguagem canônica, o Romano Pontífice.

Palavras-chave: Igreja Católica. Forma de governo. Regime político. Suprema Autoridade da Igreja Católica. Romano Pontífice. Santa Sé.
\end{abstract}

\begin{abstract}
:
The present article aims to explain to people interested on international law the form of government and the political regime of the Catholic Church, and this way make clear two consequences. The first is that what you affirm about these two aspects of the Catholic Church you also do about the Supreme Authority of the Catholic Church, i.e., the Pope and the Holly See. Secondly, the Supreme Authority of the Catholic Church and the Holly See are two expressions with the same meaning, i.e., they express the same reality or, in other words, the Pope, or in canonical terms, the Roman Pontiff.
\end{abstract}

Keywords: Catholic Church. Form of government. Political regime. Supreme Authority of the Catholic Church. Roman Pontiff. Holly See.

Introdução

Devido ao enorme interesse da Mídia suscitado pela morte recente do Papa João Paulo II e a realização do Conclave, que determinou o seu sucessor, Bento XVI, este artigo objetiva explicar para os interessados neste assunto, sobretudo para os estudantes do Direito Internacional, a forma e o regime de governo da Igreja Católica, para, em seguida, poder entender que o que se afirma sobre a forma de governo da Igreja Católica, está-se afirmando também sobre a Suprema Autoridade da Igreja Católica (o Papa) e a Santa Sé, evidenciando assim, ao final, que a Suprema Autoridade da Igreja Católica e a Santa Sé são duas expressões com o mesmo significado, vale dizer, expressam a mesma realidade, a saber, o Papa ou, na linguagem canônica, o Romano Pontífice.

\footnotetext{
1 Professor e Doutor em Direito Internacional pela Faculdade de Direito da Universidade de São Paulo.
} 
Apresso-me em dizer, porém, que este tema do qual nos ocuparemos a seguir nunca foi objeto de definição magisterial propriamente dita, por parte da autoridade eclesiástica. Isto significa que a questão está aberta à pesquisa no campo doutrinal. Também a doutrina, por sua vez, especialmente o Direito Canônico e o Direito Público Eclesiástico, não tratou desse tema. Exceção seja feita, porém, a dois autores, a saber: Francisco Suares (XVI) e Francesco D’Ostilio, Autor nosso contemporâneo, que ousaram definir a questão da forma e do regime da Igreja, embora sem se aprofundarem no assunto. Seguindo a trilha aberta pelo referido Mestre e, sobretudo, por este último, que reputamos a mais correta no enfoque do problema, procuraremos no presente artigo aprofundar a mencionada questão. O nosso esforço, portanto, deve ser entendido como uma contribuição para esclarecer o referido tema. As fontes que utilizaremos para a nossa abordagem do tema em apreço são as informações escriturísticas, doutrinais, aliadas a uma atenta e estudiosa compreensão da tradição da Igreja, somadas à observação da estrutura canônica da Igreja, bem como da práxis histórica da mesma, sobretudo no que se refere à sua atividade no campo internacional, vale dizer, na relação da Igreja (Santa Sé) com os Estados.

De posse desses dados, procuramos aplicá-las aos conceitos de forma e regime de governo fornecidos pela Teoria Geral do Estado e pelo Direito Constitucional.

\section{Instituição do Poder da Igreja Católica}

A fundamentação do poder da Igreja, explica Rafael Llano Cifuentes, "encontra-se principalmente na Sagrada Escritura e na sua própria natureza e desenvolvimento". 2

No Novo Testamento destacam-se três elementos, segundo o referido Autor:

1. O fim da Igreja: consiste na santificação de seus membros no tempo e a sua salvação eterna; ${ }^{3}$

2. Autoridade: “(...) Cristo quis constituir a Igreja com uma autoridade independente, com um poder soberano e exclusivo de dirigir os seus membros à consecução do fim comum". ${ }^{4}$ Por isso, “(...) Jesus escolheu doze homens

\footnotetext{
2 LLANO CIFUENTES, Rafael. Curso de Direito Canônico. A Igreja e o Estado à luz do Vaticano II. São Paulo: Saraiva, 1971. p. 24.

3 Jô, 18, 36-38: "Meu Reino não é deste mundo; se deste mundo fosse meu Reino, meus ministros teriam lutado para que eu não fosse entregue aos judeus; mas meu Reino não é daqui. Disse-lhe então Pilatos: logo tu és Rei? Respondeu Jesus: tu o disseste: eu sou Rei. Para isto nasci e para isto vim ao mundo, para dar testemunho da verdade". Cf. LLANO CIFUENTES, Rafael. op. cit., p. 24.

4 Cf. LLANO CIFUENTES, Rafael. op. cit., p. 25.
} 
entre seus discipulos, com o intuito de prepará-los para um especial ministério apostólico de direção". ${ }^{5} \mathrm{E}$ é a eles que Cristo diz: "Quem vos recebe, a mim recebe; e quem me recebe a mim, recebe aquele que me enviou". ${ }^{6}$ Cristo, porém, não se limita a escolhê-los; confere-lhes uma autoridade, um poder de governar: "Em verdade vos digo, que tudo o que ligardes na terra será ligado no céu e tudo o que desligardes na terra será desligado no céu". ${ }^{7}$ Servindose desta metáfora, tão comum na linguagem canônica, "ligar e desligar", que significa proibir ou permitir, Cristo entendia dar a seus discípulos uma inegável autoridade governativa e um poder supremo de jurisdição, que abarca a possibilidade de condenar e de excluir da Igreja qualquer um de seus membros. ${ }^{8}$

3. Essa autoridade, prossegue Rafael Llano Cifuentes, ele a centraliza numa pessoa concreta, a saber, Pedro, quando diz:

"Tu és Pedro e sobre esta pedra edificarei a minha Igreja e as portas do inferno não prevalecerão contra ela. Dar-te-ei as chaves do Reino dos Céus e tudo quanto ligares na terra será ligado nos Céus e tudo quanto desligares na terra será desligado nos Céus".

A pedra fundamental (Pedro), acrescenta o referido Autor, base jurisdicional da Igreja, tem, além do poder de atar e desatar, aquele "poder das chaves" que sempre havia considerado - inclusive em outros lugares paralelos do Antigo Testamento - como o símbolo do poder soberano. Pedro - e os seus sucessores -, a quem se entregaram as chaves do reino dos céus - como tradicionalmente se faz com aquele a quem se outorga o domingo duma cidade ou dum Reino - tem o poder supremo da Igreja, Reino de Deus na terra. ${ }^{10}$ Mas ainda, afirma o referido Autor: Cristo, como que querendo pôr em relevo o caráter social e hierárquico da Igreja, no ambiente de solenidade de que estava revestida a sua despedida, antes da ascensão aos céus diz aos apóstolos:

Foi me dado todo o poder no céu e na terra. Ide, pois, ensinai a todas as gentes, batizando-as em nome do Pai, do Filho e do Espírito Santo, ensinando-os a observar todas as coisas

\footnotetext{
5 Mt 1, 2-4; Mc 3, 13-19; Lc 6, 13-16; Jo 10, 2-4. Cf. LLANO CIFUENTES, Rafael. Curso de Direito Canônico. A Igreja e o Estado à luz do Vaticano II. São Paulo: Saraiva, 1971. p. 25.

6 Mt 10,40.

7 Mt 18, 28.

8 Mc 16. Cf. LLANO CIFUENTES, Rafael. op. cit., p. 25.

9 Mt 18-20. Cf. Id. Ibid., p. 25

${ }^{10}$ Id. Ibid., p. 25
} 
que vos tenham mandado até a consumação dos séculos. ${ }^{11}$ Recebei o Espírito Santo: aqueles a quem vós perdoardes os pecados, ser-lhes-ão perdoados, e aqueles a quem vós os retiverdes, ser-lhes-ão retidos. ${ }^{12}$

Ainterpretação mais estrita deste texto, arremata o referido Autor, referendada por numerosos estudos escriturísticos, deixa claro que Cristo, de um modo explícito, quis a Igreja como sociedade estabelecida com um poder soberano hierarquicamente constituído. ${ }^{13}$

Isto posto, Rafael Llanos Cifuentes chega às seguintes conclusões:

1. “(..) imediatamente após a ascensão de Jesus, os apóstolos formaram uma sociedade perfeitamente organizada $e$ reconhecida por todos, sem que houvesse necessidade de prévio estudo, discussão e votação"; ${ }^{14}$

2. “(...) esta ordem existe ainda na atualidade como um fato histórico incontestável'; 15

3. “(...) só depois de diversos séculos em circunstâncias em que a política e as ambições pessoais tiveram um papel fundamental, é que se chegou a discutir a vontade de Cristo de formar uma sociedade visivel, com uma sociedade hierárquica, soberana na sua ordem, independentemente do poder civil"; 16

4. "Cristo, que quis formar uma sociedade independente e suprema na sua ordem, dotou-a dos meios necessários - assistência do Espírito Santo, Sacramentos, etc. - para atingir o seu fim". ${ }^{17}$

Além da fundamentação escriturística, afirma o referido Autor, o poder da Igreja será dica na sua própria natureza, através das seguintes características: ${ }^{18}$

1. trata-se de uma sociedade sobrenatural e espiritual, ou seja, que emprega meios sobrenaturais para alcançar fins espirituais, ou seja, o bem comum sobrenatural: a santificação dos seus membros ou a salvação das almas

\footnotetext{
${ }^{11}$ Mt, 28, 18-20. Cf. LLANO CIFUENTES, Rafael. Curso de Direito Canônico. A Igreja e o Estado à luz do Vaticano II. São Paulo: Saraiva, 1971. p. 25-26

12 Jó, 19, 20. Cf. Id. Ibid., p. 26

13 Jó, 19, 20. Cf. Id. Ibid., p. 25-26

${ }^{14}$ Cf. Id. Ibid., p. 26, citando MARIN, N. Lecciones de Apologetica. T. II, San Sebastián, 1939, p. 210

${ }^{15}$ LLANO CIFUENTES, Rafael., op. cit., p. 26 citando MARIN, N. op. cit.

${ }^{16}$ Id. Ibid, p. 26 citando Id. Ibid.

${ }^{17}$ LLANO CIFUENTES, Rafael., op. cit., p. 26

${ }^{18}$ Id. Ibid., p. 24
} 
(Salus Animarum). ${ }^{19}$ Em outras palavras, trata-se de uma corporação institucional, ouse seja, que "o substrato social está constituído por uma coletividade de homens que congregam na consecução dum mesmo fim"; 20

2. fundada diretamente pelo próprio Cristo e, por isso, exerce o seu poder de modo soberano, originário e autônomo, vale dizer, exercita o poder de modo independente, com capacidade para determinar a própria competência; ${ }^{21}$

3. cuja unidade e universalidade faz estender a sua ação para além das fronteiras dos Estados, ${ }^{22}$ isto é, o seu raio de ação é global e não-somente territorial: ${ }^{23}$

4. e perene, ${ }^{24}$ vale dizer, a busca da realização dos seus objetivos só termina quando o próprio Cristo, seu fundador, cumprir a promessa de voltar para julgar os vivos e os mortos (Maranatá).

Por último, acrescenta o referido Autor, o poder da Igreja é demonstrado através de uma práxis histórica de convivência "com uma enorme diversidade de nações, raças e línguas, que há cerca de 21 séculos estão socialmente unidas para procurar idênticos fins, empregando meios sobrenaturais, obedecendo à mesma autoridade suprema e lutando, às vezes às custas da própria vida, para manter a independência do regime e a autonomia da soberania com que Cristo quis datar a Igreja". ${ }^{25}$

Portanto, quanto à instituição do poder da Igreja na sociedade, resulta que ele tem a sua origem e legitimação ex ispa ordinatione divina, ou seja, parte de modo imediato a própria autoridade de seu fundador, vale dizer, Nosso Senhor Jesus Cristo. Conseqüentemente, "as estruturas constitucionais ou institucionais da Igreja na sociedade estão no seu fundamento determinadas diretamente por Deus". ${ }^{26}$ Por esta razão, nem o

\footnotetext{
${ }^{19}$ LLANO CIFUENTES, Rafael. Curso de Direito Canônico. A Igreja e o Estado à luz do Vaticano II. São Paulo: Saraiva, 1971. p. 27 e 29

${ }^{20}$ Id. Ibid., p. 29

${ }^{21}$ Id. Ibid., p. 29

22 Id. Ibid., p. 27

23 “A Constituição e atividade da Igreja são independentes de qualquer nexo ou limitação de caráter especial, de tal modo que o território não concorre de maneira alguma na constituição do conceito de Igreja. O aumento ou a diminuição de território não modifica o essencial universalismo da Igreja, porque seu 'catolicismo' não depende só da universalidade geográfica que abrange mas, especialmente, da natureza de sua estrutura jurídica que está destinada à gente 'de toda raça e de toda língua' (Mt, 28, 18-20). Daí que os conceitos de 'Igreja Católica'e 'Igreja Nacional' sejam antitéticos. O território interessa apenas como determinação especial da organização da atividade da Igreja (diocese, paróquia, prelatura, território de missão, etc.)". Cf. Id. Ibid., p. 29

${ }^{24}$ Id. Ibid., p. 27

${ }^{25}$ Id. Ibid., p. 27-28

${ }^{26}$ Id. Ibid., p. 33
} 
exercício, nem a legitimação de tal direito derivam de qualquer autoridade humana, muito menos da estatal ou de determinada forma de governo estatal. Como se verá mais adiante, a Igreja tem a sua própria forma de governo, ainda que bastante sui generis em relação às demais formas de governos atuais, mas, contudo, eficaz na obtenção do seu bem comum, ou seja, a salvação das almas (salus animarum). A Igreja exerce este seu poder com total soberania ou independência na consecução dos seus objetivos em relação às demais ordens constitucionais.

\section{Como o Poder da Igreja Católica se Estrutura na Sociedade}

Em primeiro lugar, é preciso dizer com Jean Yves Lacoste, que o poder institucional fundamental da Igreja não se encontra estabelecido em uma Carta Constitucional, ${ }^{27}$ porque a Igreja não a possui, ${ }^{28}$ mas encontra-se codificado no meio de outros regulamentos, principalmente no Código de Direito Canônico, de 1983, (CIC). ${ }^{29}$ Sustenta-a, prossegue o referido Autor, a convicção de que a instituição visível da Igreja encarna a realidade religiosa da graça. ${ }^{30}$ Vale dizer, explica Rafael Llano Cifuentes, a Igreja constitui "o Corpo Místico de Cristo e o Povo de Deus. O primeiro aspecto denota o seu caráter vital e interno, propriamente dito. O segundo aspecto se refere a sua natureza histórica e social". ${ }^{31}$

Enquanto Corpo Místico de Cristo, prossegue o referido Autor, os que pertencem à Igreja estão unidos entre si, formando um só corpo espiritual, místico, cuja cabeça é Cristo. Desta maneira, não formam uma mera comunidade humana, não constituem simplesmente uma pessoa moral ou jurídica de índole religiosa, mas, pelo

\footnotetext{
${ }^{27}$ SILVA, José Afonso da. Curso de Direito Constitucional Positivo. São Paulo: Malheiros, 2000. p. 36: O Direito Constitucional tem por objetivo "as normas fundamentais da organização do Estado, isto é, pelas normas relativas à estrutura do Estado, forma de governo, modo de aquisição e exercício do poder, estabelecimento de seu órgãos, limites de sua atuação, direito fundamentais do homem e respectivas garantias e regras básicas da ordem econômica e social". Conteúdo formal: "Tem-se a lei fundamental de um povo, ou o conjunto de regras jurídicas dotadas de máxima eficácia, concernentes à organização e ao funcionamento do Estado". DALLARI, Dalmo de Abreu. Elementos de Teoria Geral do Estado. São Paulo: Saraiva, 1972. p. 176-177.

${ }^{28}$ Já houve, na década de 70, a tentativa de se criar uma Carta Constitucional no sentido moderno a ela atribuída pelo Direito Constitucional, ou seja, reunir em uma Constituição as normas fundamentais de todo o Direito Eclesiástico, tanto da Igreja Católica Latina quanto da Igreja Católica Oriental. Contudo, não prosperou tal projeto. Este foi distribuído ao longo dos livros que atualmente compõem o Código de Direito Canônico de 1983, CIC. Para aprofundamento, consulte: Projeto de Lei Fundamental . In: SEDOC, n. 39, 1971, p. $435-$ 467; Concilium, v. 56, n. 6, 1970, p. 799-813; HEIMERI, H. Bases para um Código Constitucional da Igreja. Concilium, n. 6, p. 59-64, jun. 1967.

${ }^{29}$ LACOSTE, Jean Yves. Dicionário Crítico de Teologia. São Paulo: Paulinas e Loyola, 2004. p. 774

${ }^{30}$ Id. Ibid., p. 774

${ }^{31}$ LLANO CIFUENTES, Rafael. op. cit., p. 2.
} 
contrário, participam duma unidade intima ${ }^{32}$ que nos compromete numa mesma vida denominada sobrenatural ou vida de graça. ${ }^{33}$

O elo ou a coerência que vincula os membros do Corpo de Cristo entre si, segundo este Autor, é dado pela cooperação dos mesmos para alcançar o fim comum, ou seja, a salvação das almas; mas, sobretudo, através do Espírito Santo, que é o principio interno de tal corpo. Trata-se de um princípio não de ordem natural, mas sobrenatural; mais ainda, absolutamente infinito e incriado em si mesmo, que atuando de fato e impregnando a contextura de união e cada uma das suas partes, é de tal excelência, que por si mesmo ultrapassa imensamente todos os vínculos de unidade que servem para a união do corpo físico ou moral. ${ }^{34}$

Isto significa que a Igreja, avança o referido Autor, em princípio, não pode ser analisada como mais uma forma de agrupamento social, como nas demais sociedades, porque o seu substrato fundamental da união social é algo que, ultrapassando o sóciojurídico, chega ao sobrenatural: a própria vida de Cristo comunicada pelos sacramentos, vínculo essencial do Corpo Místico. ${ }^{35}$

Enquanto o Povo de Deus, explica o mesmo Autor, a Igreja não se reduz, porém, a uma pura comunidade de espíritos, mística e intensa; está formada de homens e para os homens, os quais constituem externamente uma verdadeira comunidade social e histórica: o Povo de Deus. O Senhor quis - proclama a Constituição Lúmen Gentium do Concílio Vaticano II - santificar e salvar os homens, não-individualmente e isolados entre si, mas constituí-los num povo, que o conhecesse na verdade e certamente o servisse. Esta designação visualizada a Igreja - à semelhança do povo israelita - como povo peregrino, atravessando o deserto da História, por cima de toda divisão cultural, racial ou política, à procura da cidade eterna, vivendo em ordem hierárquica para a realização do Reino de Deus sobre a terra ${ }^{36}$ Como povo de Deus, afirma o legislador canônico, a Igreja compõe-se de crentes, entre os quais existe quanto à dignidade e à atividade uma verdadeira igualdade - Sacramento do Batismo -, em virtude da qual todos cooperam para a edificação do Corpo de Cristo, segundo a condição e a função próprias de cada um (Cân.. 208, CIC). ${ }^{37 / 38}$

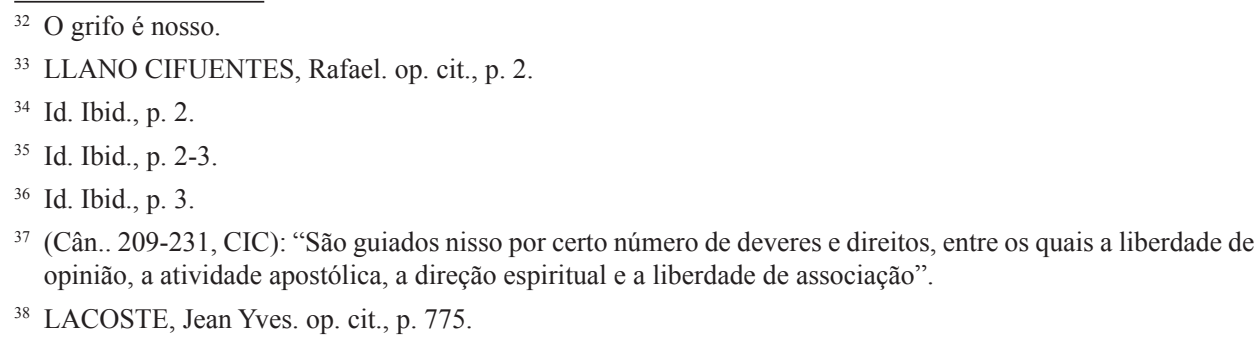


Sobre isso, afirmou o Papa Paulo VI:

(...) A Igreja, pelo contrário, é precisamente uma sociedade jurídica, organizada, visivel, perfeita.

(...) Assim quis o Senhor a sua Igreja: uma verdadeira sociedade perfeita e soberana, com leis próprias, com autoridade própria, com meios e fins próprios. É esta uma verdade fundamental da doutrina católica, que tem sólidas e claras raizes no Novo Testamento e uma realidade evidente na história da Igreja. ${ }^{39}$

Assim, retoma Rafael Llano Cifuentes, se levarmos em consideração o caráter social da Igreja, não poderemos suprimir dela a estrutura jurídica nem a atividade legislativa. ${ }^{40}$

Nesse sentido, acode o Papa Paulo VI, ao afirmar:

(...) Mas não vemos como a Igreja Católica, se quer permanecer fiel e ser conseqüente com os princípios construtivos dados por seu Divino Fundador, pode prescindir de dar-se a si mesma um "direito canônico": e a Igreja é uma sociedade visível, hierárquica, comprometida numa missão salvadora, que não admite senão uma unívoca e determinada realização, que deve ser conservada rigorosamente e definida apostolicamente, responsável pela saúde dos próprios fiéis e da evangelização do mundo, não pode deixar de estabelecer leis, derivadas coerentemente da Revelação e das necessidades que brotam continuamente da sua vida interior e exterior. ${ }^{41}$

Assim, segundo o cardeal Felici, a Igreja, por ser uma comunidade não-só espiritual, mas visível, orgânica, hierárquica, social e ordenada, tem necessidades também de uma lei escrita e requer órgãos adequados que a promulguem e a façam observar nãosó por mero exercício da autoridade, mas precisamente para a tutela da essência e da liberdade, tanto dos entes morais quanto das pessoas físicas que compõem a Igreja. ${ }^{42}$

Em síntese, conclui Rafael Llano Cifuentes, a realidade institucional do poder da Igreja na sociedade surge nas suas dimensões complementares interna e externa,

\footnotetext{
39 PAULO VI. Alocução de 26-5-1966.

40 LLANO CIFUENTES, Rafael., op. cit., p. 5.

${ }^{41}$ PAULO VI. Alocução de 17-8-1968. LLANO CIFUENTES, Rafael., op. cit., p. 8.

42 Cardeal Felici, presidente da Comissão Pontifícia para a revisão do código de Direito Canônico, na conferência pronunciada na Universidade Lateranense, em 25 de outubro de 1967: citado por LLANO CIFUENTES, Rafael., op. cit., p. 8.
} 
vital e histórica ou social, espiritual e jurídica, enquanto o Corpo Místico de Cristo e Povo de Deus. ${ }^{43}$

\section{A Estrutura da Igreja Católica Latina ${ }^{44}$}

Segundo Jean Yves Lacoste, a Igreja estrutura-se verticalmente em Igreja Universal, Igreja Local ou Particular (Diocese) e Comunidade ou Paróquia. A autoridade é exercida por um poder eclesial (sacra potestas), organizado hierarquicamente e de direito divino, no seio do qual há que distinguir o poder de ordem (potestas ordinis) e o poder de jurisdição (potestas jurisdicitionis). O primeiro é conferido pelo sacramento da ordem, é absolutamente inalienável e compõe-se de atribuições ligadas à ordenação episcopal, presbiterial ou diacional. O segundo pode ser limitado no tempo e subdivide-se em poderes legislativo, executivo e judiciário. O Papa detém a jurisdição suprema sobre a Igreja Universal, ${ }^{45}$ sobre todas as Igrejas Locais ou Particulares (Dioceses) e sobre todo crente: sua autoridade é ilimitada ${ }^{46}$ e não depende de nenhum outro órgão de Governo. ${ }^{47}$

${ }^{43}$ LLANO CIFUENTES, Rafael. Curso de Direito Canônico. A Igreja e o Estado à luz do Vaticano II. São Paulo: Saraiva, 1971. p. 8.

44 Para não prolongar este nosso trabalho, dispensamo-nos de mostrar, aqui, a estrutura detalhada, mas apenas a grosso modo da Igreja Católica Oriental, uma vez que isto nada acrescenta ao tema que estamos tratando neste artigo. Para aprofundamento, consulte o Código de Direito Canônico para as Igrejas Orientais, promulgado pelo Papa João Paulo II em 1990: Estruturas da Igreja Universal: Suprema Autoridade da Igreja (42-54); Romano Pontífice (Papa) (43-48); Colégio dos Bispos (49-54). Estruturas das Igrejas Orientais: Igrejas Patriarcas (114-125); Sé Patriarcal Vacante ou Impedida (126-132); Metropolitas da Igreja Patriarcal (133139); Concílio Patriarcal (140-145); Território fora da Igreja Patriarcal (146-150). Igrejas Arcebispais maiores (151-154). Igrejas Metropolitanas sui iuris (155-173); Outras Igrejas sui iuris (174-176). Eparquias e Bispos (177-310): Bispos (177-234); Cúria Eparquial (242-263); paróquias, párocos e Vigários Parquiais (279-303); Reitores de Igrejas (304-310). Esarquias e Esarcos (311-321). Assembléia de Esarcos de demais Igrejas sui iuris (323-398): Cf. D’OSTILIO, Francesco. Prontuario del Codice di Diritto Canônico. Città del Vaticano: Libreria Editrice Vaticano, 1994. p. 170.

${ }^{45} \mathrm{Na}$ verdade, o sujeito do poder supremo e pleno na Igreja, além do Papa, é também o Colégio de Bispos, e isso por direito divino. Aquele primeiro é sempre a cabeça desse último. Trata-se de um paralelismo de igualdade, mas também é distinção entre eles: o cabeça pode agir sem o Colégio, mas este não pode agir sem aquele. Em outras palavras, o Papa é sempre a Suprema Autoridade (Cân., 336-341). Cf. HORTAL, Jesus. Comentário ao Cân.. 336 do Código de Direito Canônico. São Paulo: Loyola, 1983. p. 154-155: "Já durante o Concílio, mas especialmente depois, tem-se discutido sobre as relações entre o Colégio Episcopal e a sua cabeça: trata-se de dois sujeitos diferentes? Nem o concílio, nem o Código dirimem a questão. Inclinamo-nos pela opinião de que se trata de dois sujeitos inadequadamente distintos e não apenas de um sujeito (o Colégio Episcopal) que atuaria de dois modos diversos (pessoalmente, através de sua cabeça, e colegialmente, ou seja, através do Colégio Episcopal)".

46 No item 6, "A igreja: forma de governo", discutiremos mais detalhadamente se o poder de governo do Papa possui limites ou é absoluto.

${ }^{47}$ LACOSTE, Jean Yves. op. cit., p. 775. 
A natureza do poder de governo do Papa ${ }^{48}$ como afirma Gianfranco Ghirlanda, tem as seguintes características: ordinária, suprema, plena, imediata, inclui o primado de honra sobre toda a Igreja; Roma, enquanto a primeira sede de Pedro de governo: poder legislativo - fazer leis universais para toda a Igreja ou particulares e dispensar das mesmas; poder executivo ou administrativo - reserva de penas eclesiásticas; disciplina da liturgia e dos sacramentos; direção suprema dos institutos de vida consagrada; controle geral sobre os bens temporais das Igrejas Particulares ou Locais (dioceses); poder judiciário - avocar a si qualquer causa; juízo dos chefes de Estado, dos cardeais, patriarcas, legados e núncios apostólicos e bispos em causas criminais, direito de não ser julgada por ninguém; primado de magistério - infalibilidade ex catedra (só ensinamento em questões de fé e de moral); condenar doutrinas errôneas ou livros perigosos; proclamação e supressão dos institutos de viça consagrada. ${ }^{49}$

De acordo com Jean Yves Lacoste, ${ }^{50}$ o Papa é eleito pelos membros do Colégio de Cardeais que não tenham completado os oitenta anos de idade no momento em que a sede de Roma tornou-se vacante, e reveste sua dignidade (se já for bispo) pelo simples fato de aceitar sua eleição. Só a perde em casos de renúncia, ${ }^{51}$ morte, demência perpétua, heresia formal, apostasia. ${ }^{52}$ Dispõe, para exercer seu ministério universal, do Sínodo dos Bispos, ${ }^{53}$ do Colégio de Cardeais, ${ }^{54}$ da Cúria Romana, ${ }^{55}$ dos Legados e Núncios Apostólicos. ${ }^{56 / 57}$

${ }^{48}$ Em linguagem canônica, o Papa enquanto Suprema Autoridade da Igreja é chamado sempre de Sumo Pontífice. O termo Papa tem conotação mais familiar.

49 GHIRLANDA, Gianfranco. Il diritto nel mistero della Chiesa. Roma, 1985/86, p. 125-126. Cf. Cân.on 331 do Código de Direito Canônico de 1983 (CIC).

${ }^{50}$ Retratando a Constituição Apostólica Universi Dominici Gregis, 22/02/1996 (AAS, 88, 1996), p. $3^{\text {a }-5, ~} 342$.

51 Como o Papa é a Suprema Autoridade da Igreja, o Cân.. 332, § 2 do CIC, só exige que tal renúncia seja feita de modo livre e devidamente manifestado, mas não deve ser aceito por ninguém.

52 Papa Paulo VI. Motu Próprio Ingravescentem Aetatem, II, 2 (AAS 62 [1970], 811). Papa Paulo VI. Constituição Apostólica Universi Dominici Gregis. Op. cit., p. 305-342. BARBOSA JÚNIOR, Tiago Wenceslau. A eleição do Romano Pontífice, segundo a Constituição Apostólica Universi Dominici Gregis promulgada pelo Santo Padre João Paulo II a 22 de fevereiro de 1996. Revista de Cultura Teológica, São Paulo, dez. 2004 e GHIRLANDA,Gianfranco. op. cit., p. 127.

53 Geralmente tem caráter consultivo; sua finalidade é representar o episcopado, prestando ajuda e conselho ao Papa nas questões que envolvam fé, costume, disciplina eclesiástica e problemas referentes à atividade da Igreja no mundo (Cân.. 342-349; CIC).

54 Trata-se de um colégio especial, ao qual compete assegurar a eleição do Papa; também, aconselham o mesmo nas questões de maior importância para a Igreja, ou individualmente nos diversos ofícios que exercem junto à Cúria Romana (Cân.. 349-359; CIC).

55 Cân.. 360-361.

${ }^{56}$ O Legado é um representante do Papa de caráter transitório, ou seja, para missões especificas e pontuais junto aos Governos Nacionais ou junto à Igreja Nacional, geralmente um Cardeal, enquanto que o Núncio (embaixador) representa a pessoa do Papa de modo estável junto àquelas duas instâncias nacionais, ou seja, governo e Igreja Católica do Estado (Cân.. 362-367; CIC).

57 LACOSTE, Jean Yves. op. cit., p. 775. 
O bispo, prossegue o referido Autor, recebe seu ministério por delegação do Papa, dirige uma Igreja local (diocese), da qual é o legislador, administrador e juiz supremo. Apóia-se nessas funções numa Cúria Diocesana, que reúne os titulares de diversos cargos: vigário geral, vigário episcopal, oficial, chanceler, notários, Conselho de Administração dos bens episcopais e Ecônomo. O bispo costuma ser aconselhado por uma espécie de Senado, ou seja, de Padres Diocesanos denominados de Capítulo da Catedral ou também de Colégio de Consultores. Os bispos pertencem ao Colégio Episcopal, cujos membros estão hierarquicamente unidos (comunio hierarchica) a seu chefe, o Papa; fora dessa união, não são portadores do Poder Supremo da Igreja, nem nos Concílios Ecumênicos, nem nos atos oficiais comuns que comprem pelo mundo. Os bispos, além disso, estão geralmente reunidos no âmbito de uma Conferência Episcopal de caráter nacional. No nível da Paróquia, explica o referido Autor, é o Pároco que exerce as responsabilidades do governo - ou do poder - (por delegação do bispo). Esta construção rigorosamente hierárquica está ligada por polaridade a um Princípio Sinodal de Co-responsabilidade, vale dizer, à colaboração de todos os membros da Igreja segundo o seu estatuto. Esse princípio se manifesta no nível da Igreja Universal, no Concílio Ecumênico e no Sínodo dos Bispos (que é, desde 1965, uma assembléia dos bispos de diferentes regiões, que serve de órgão consultivo junto ao Papa). No nível da Igreja Regional ou Episcopal (Assembléia Permanente dos Bispos de uma região ou de um país que ali exercem colegialmente suas responsabilidades pastorais; é instituído pelo Papa e constitui uma pessoa moral distinta), afirma o referido Autor, assim como nos concílios regionais (Concílio Pleno para a zona da competência de uma conferência episcopal; Concílio Província Eclesiástica); no nível Diocesano ou Particular, segundo o referido Autor, no Sínodo Diocesano, no Conselho Presbiteral, no Conselho de Administração dos bens diocesanos; no nível da paróquia, arremata o referido Autor, no conselho pastoral de administração dos bens paroquianos. Todos esses Órgãos Sinodal - com exceção do Concílio Ecumênico e das instâncias que administram os bens das Igrejas Diocesanas - têm apenas um papel consultivo, e não põem em causa o Princípio Hierárquico..$^{58}$

\section{A Natureza do Direito Canônico ou Eclesial}

Segundo o Papa Paulo VI, explica Gianfranco Ghirlanda, a natureza do Direito Canônico ou Eclesial fundamenta-se no conceito de "sociedade perfeita", vale dizer, soberana ou independente, e no princípio jurídico ubi societas ibi ius. Trata-se esta

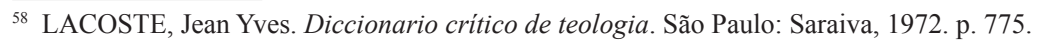


de uma especificação de cunho filosófico e não-teológico. Todavia, nunca tal Direito pode ser considerado de modo formalístico e não-teológico. Todavia, nunca tal Direito pode ser considerado de modo formalístico e positivístico. ${ }^{59}$ Isto porque o Direito Eclesial ou Canônico, prossegue o referido Autor, baseia-se no principio evangélico fundamental da caridade, enquanto que o seu sentido se encontra naquilo que é o Ministério da Igreja (Corpo Místico/Povo de Deus). Daí que o referido Direito deve interpretar a lei divina e a lei da consciência e faz parte da ação salvífica de Deus. ${ }^{60}$ Já o Papa João Paulo II, retoma o referido Autor, ensina que este mesmo Direito deve traduzir a relação entre justiça, aequitas e caridade no sentido em que, espelhando-se na Justiça Divina, a função judiciária na Igreja deve estar a serviço da verdade e da caridade, que, por sua vez, gera a aequitas canonica.$^{61}$ Assim, afirma o referido Autor, o Direito Eclesial ou Canônico deve buscar o bem comum da Igreja, entendido enquanto a realização da vida da comunhão da própria Trindade (Pai, Filho e Espírito Santo) na vida de cada fiel e de toda a Igreja. É nesse contexto que deve ser considerada a pessoa humana ou o fiel, quanto aos seus direitos fundamentais de ordem sobrenatural em relação à função do ministério hierárquico. ${ }^{62} \mathrm{E}$, portanto, a caridade divina redentora que revela a verdadeira realidade do homem ou do fiel: o reconhecimento da dimensão do homem criado e salvado pela caridade divina, que deve ser o fundamento da justiça e do sistema jurídico da Igreja. ${ }^{63}$ A Igreja, portanto, arremata o referido Autor, deve colocar-se como um modelo de integração entre o desenvolvimento ordenado da sociedade e a realização da personalidade do homem que vive em uma comunidade de fé, de esperança e de caridade. ${ }^{64}$

Portanto, conclui o referido Autor, a função do Direito Eclesial é ajudar o homem na superação do seu individualismo e abri-lo à sua vocação pessoal e comunitária. O Direito Eclesial, então, possui dois pólos: tutela da comunhão eclesial e tutela dos direitos de cada fiel. A opção fundamental da Igreja é ser espelho da justiça (speculum iusticiae) na tutela dos direito fundamentais do homem. ${ }^{65}$

Em síntese, o poder da Igreja se estrutura na sociedade de modo soberano, porque fundado pelo próprio Cristo e, por isso, exerce seu poder de modo originário

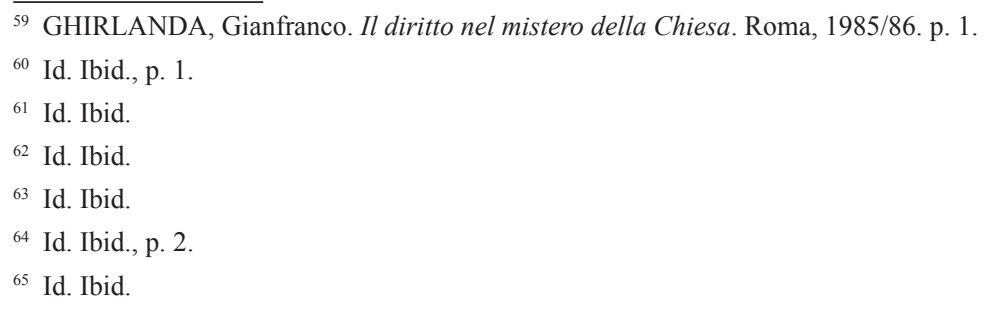


e autônomo, vale dizer, independente, com capacidade para determinar a própria competência; é uno e universal, porque a ação da Igreja não conhece fronteiras, ou seja, sua geopolítica é de espectro global; é perene, porque a sua missão salvadora só se esgota quando seu fundador voltar e, portanto, sua ação dura até o final dos tempos; possui uma autoridade organizada hierarquicamente, tendo o Papa como Suprema Autoridade da mesma; é de natureza sobrenatural e espiritual, pois emprega meios sobrenaturais (Cristo e a sua graça) para alcançar fins espirituais, a saber: a salvação das almas; é dotada de leis próprias, principalmente o Código de Direito Canônico, para o seu autogoverno e para a sua relação com os Estados, fundamentais no conceito de Igreja como sociedade perfeita (soberana ou independente) e no principio jurídico ubi societas ibi ius; é corpo de Cristo porque estabelece uma unidade íntima entre os seus membros, a saber: o Espírito Santo, além da cooperação entre os mesmos; é Povo de Deus, porque se encarna em comunidade formada de homens e, por isso, é social e histórica.

5. Quem É o Detentor do Poder da Igreja e como se Relaciona com os seus Fiéis?

Como já vimos no item 1 (Instituição do poder da Igreja), Cristo quis constituir a Igreja com uma autoridade independente, com um poder soberano e exclusivo de dirigir os seus membros à consecução do fím comum. Nesse sentido, afirma Rafael Llano Cifuentes, Jesus escolheu doze homens entre os seus discípulos, com o intuito de prepará-los para um especial ministério apostólico de direção. ${ }^{66} \mathrm{~A}$ esses, pois, continua o referido Autor, Cristo conferiu uma autoridade e um poder de governar, vale dizer, de "ligar e desligar", "proibir e permitir". Assim, Cristo entendia dar a seus discípulos uma inegável autoridade governativa e um poder supremo de jurisdição, que abarca a possibilidade de condenar e de excluir da Igreja qualquer um dos seus membros. ${ }^{67}$ Essa autoridade, prossegue o referido Autor, Cristo a centralizou numa pessoa concreta, a saber: em Pedro, um dos Doze Apóstolos. ${ }^{68}$ Assim, por vontade direta de Jesus, Pedro tornouse a pedra fundamental da Igreja, ou, em outras palavras, o Apóstolo Pedro se tornou a base jurisdicional "suprema" da Igreja - ou seja, enquanto cabeça da mesma, Pedro tem, além do poder de atar e desatar, aquele "poder das chaves", símbolo do poder soberano. Observe-se, porém, que o poder das chaves também foi dado pelo mesmo Senhor aos

\footnotetext{
${ }^{66}$ Mt, 1, 2-4; Mc, 3, 13-19; Lc, 6, 13-16; Jó, 10, 2-4. LLANO, CIFUENTES, R. Curso de Direito Canônico. A Igreja e o Estado à luz do Vaticano II. São Paulo: Saraiva, 1971. p. 25.

${ }^{67}$ Mc, 16. 16. LLANO CIFUENTES. R., op. cit., p. 25.

${ }^{68}$ Mt, 16, 18-20; Jó, 1, 42; Lc, 22, 31-32; Jó, 10, 16; 21, 15-18. Id. Ibid., p.25.
} 
demais Apóstolos, ${ }^{69}$ motivo pelo qual Pedro, juntamente com os outros Apóstolos, tem o poder supremo da Igreja, reino de Deus na terra, mas aquele primeiro foi posto por Jesus enquanto cabeça da Igreja ou órgão centralizador e vigário (porque exercido em nome de Cristo), além de representante da unidade eclesial, do poder soberano hierarquicamente constituído da sociedade formada pela Igreja.

Portanto, o sujeito da Suprema Autoridade na Igreja, por decisão divina, é duplo: Pedro e os Apóstolos. Nesse sentido, existe uma relação de igualdade entre esses dois beneficiários do Poder Supremo da Igreja. Mas, ao mesmo tempo, ambos são distintos entre si, no sentido em que Pedro é a cabeça dos Apóstolos, como que para indicar que a cabeça pode agir por si mesma (pessoalidade), mas o contrário não é possível.

Ora, esta instituição do Poder Supremo na Igreja, enquanto divina, é imutável e, portanto, perdurará até o final dos tempos enquanto base jurisdicional central do Poder na Igreja. ${ }^{70}$ Hoje, o sucessor de Pedro chama-se Papa ou Romano Pontífice ${ }^{71}$ para o Direito Canônico, enquanto que os sucessores dos Apóstolos chamam-se Bispos. O conjunto dos Bispos mais o Papa denomina-se Colégio dos Bispos ou Colégio Episcopal. ${ }^{72}$ Assim, os sujeitos da Suprema Autoridade na Igreja são o Papa e o Colégio dos Bispos, formando uma unidade entre eles. O primeiro, porem, é a cabeça desse ultimo. Nisto, a cabeça se distingue dos demais membros do Colégio dos Bispos. O Colégio dos Bispos nunca pode agir sem sua cabeça. Portanto, o Colégio Episcopal continua e perpetua o Colégio Apostólico instituído por Nosso Senhor Jesus Cristo, razão pela qual entre os bispos vige ininterruptamente o Principio da Colegialidade. Entre o Papa e os bispos vigora o mesmo vínculo que unia Pedro aos Apóstolos e, conseqüentemente, o Papa é a cabeça do Colégio Episcopal, como São Pedro era a cabeça do Colégio Apostólico. ${ }^{73}$ Ressalte-se, porém, que o Papa, na sua função de cabeça do Colégio Episcopal, possui unicamente a plenitude do poder pastoral, chamado de Primado, ${ }^{74}$ que não é somente de honra, bem de caráter

\footnotetext{
${ }^{69}$ LLANO CIFUENTES, Rafael. Curso de Direito Canônico. A Igreja e o Estado à luz do Vaticano II. São Paulo: Saraiva, 1971. p. 25.

${ }^{70}$ Cf. Lumen Gentium 20, caput: "Esta missão divina confiada por Cristo aos Apóstolos deverá durar até o fim dos séculos (Mt 28, 20) (...)".

${ }^{71}$ Cf. Lumen Gentium 22, Cân.. 331-335.

72 Cf. Lumen Gentium 22-23, Cân.. 336.

73 Cf. Lumen Gentium 22.

74 Por direito divino, o Papa é: - sucessor de São Pedro e, enquanto tal, revestido da mesma função de governo pastoral conferido por Cristo individualmente ao Apóstolo; - a cabeça do Colégio Episcopal, como Pedro era cabeça do Colégio Apostólico; - vigário de Jesus Cristo para a Igreja Universal; - Pastor da Igreja Universal. Por causa de seu Oficio Petrino, o poder do Papa é: ordinário - anexo ao seu oficio; supremo - não existe na Igreja nenhum poder que seja superior ou igual ou que não lhe esteja subordinado. Por isso, contra uma decisão do Papa não existe qualquer recurso de apelo: Roma locuta, causa finita est; pleno - porque não falta nenhum
} 
provincial, mas assume todo o seu significado próprio de poder jurisdicional e de governo sobre toda a Igreja. ${ }^{75} \mathrm{O}$ Colégio dos Bispos exercita seu Poder Supremo de duas formas:

$1^{\text {a) }}$ solene: quando está reunido, colegialmente, no Concílio Ecumênico;

$2^{\text {a }) ~ n a ̃ o-s o l e n e: ~ q u a n d o ~ s o l i c i t a d o ~ p e l o ~ P a p a, ~ a g e m ~ d e ~ m o d o ~ c o l e g i a l, ~ a i n d a ~}$ que dispersos pelo mundo. ${ }^{76}$

Assim, foi em trono da figura de Pedro e dos Apóstolos e, depois, de seus sucessores, isto é, o Papa e os bispos (Colégio de Bispos) enquanto detentores do Poder Supremo da Igreja é que se organizou a disciplina dos fieis na mesma. ${ }^{77}$ Sendo tal instituição da Suprema Autoridade na Igreja de natureza divina, logo, da parte dos membros da Igreja, ou seja, dos batizados, exige-se a obediência àqueles sujeitos segundo a hierarquia disposta. ${ }^{78}$ À não-obediência dos fieis se impõem as penas devidas. ${ }^{79}$

Portanto, essencialmente, a relação entre os detentores da Suprema Autoridade da Igreja e os fiéis se dá por uma relação de obediência doutrinal e disciplinar ${ }^{80}$ (relação de pastor-ovelha), em vista do fim ou do bem comum a ser alcançado, ou seja, a santificação de salvação dos fiéis a realização da sua personalidade, enquanto homem criado e salvado pela caridade divina; enquanto membro da comunidade de fé, esperança e caridade; a superação do seu individualismo para abri-lo a sua vocação pessoal e comunitária; e a tutela dos seus direitos. ${ }^{81}$

\footnotetext{
meio necessário ou útil para alcançar o seu fim: compreende o poder de ensinar, de santificar e de governar em tudo a Igreja e com todas as funções relativas; imediato - pode exercê-lo por si mesmo ou por meio de seus vigários, sobre pessoas, lugares e coisas e não é obrigado a exercê-lo através dos respectivos bispos locais; universal - se estende sobre toda a Igreja: quanto às coisas: fé, costumes, disciplina, administração, etc.; independente na sua origem, porque recebe o seu poder diretamente de Deus, e não através do Colégio de Cardeais reunidos em Conclave; independente no seu exercício: válido e lícito, porque juridicamente não é responsável perante qualquer autoridade humana; livre: porque pode exercê-lo sempre livremente. Quanto ao poder de governo ou pastoral, o Papa goza de: poder legislativo sobre toda a Igreja - em 1983, o Papa promulgou o novo Código de Direito Canônico (CIC) para toda a Igreja Latina e, em 1990, o novo Código de Direito Canônico para as Igrejas Orientais; poder judiciário - que exercita sobre toda a Igreja, através dos seus tribunais, a saber, Tribunal da Rota Romana e o Supremo Tribunal da Signatura Apostólica; poder administrativo - em virtude do seu primado, o Papa é o Administrador Supremo da Igreja. Cf. D’OSTILIO, Francesco. op. cit., p. 174-175.

${ }^{75}$ Cân., 331, CIC.

${ }^{76}$ D’OSTILIO, Francesco. op. cit., p. 183.

${ }^{77}$ At. 1, 15; 4, 34-35; 10, 47-48; 15, 22-29; 1 Cor. 7, 1-17, 39-40; 10, 20-22; 11, 6-7, 16; 14, 34; 1 Tm. 2, 9-12.

${ }^{78} 1$ Cor. 4, 21; II Cor. 7, 15; 10, 2, 6, 10-11; 13.2 ; Eb. 13, 17.

${ }^{79}$ At. 5, 1-1; 1 Cor. 5, 1-5; 1 Tm 1, 19-20; 2 Ts 3, 6, 14; Tt. 13, 10.

${ }^{80}$ Cf. Lumen Gentium 37b.

${ }^{81}$ GHARLANDIA, Gianfranco. op. cit., p. 2.
} 
6. A Igreja Católica: Forma de Governo

Por forma de Governo de um Estado, segundo José Afonso da Silva, devese entender:

A maneira como se dá a instituição do poder na sociedade e como se dá a relação entre governantes e governados. Responde à questão de quem deve exercer o poder e como este se exerce. ${ }^{82}$

Portanto, de acordo com esta definição, trata-se de determinar, em primeiro lugar, como o poder da Igreja foi instituído na sociedade. Em seguida, será necessário mostrar como esse poder se estrutura na referida sociedade e como o mesmo se relaciona com os seus governados. Dessa forma, colher-se-á, em outras palavras, quem é o detentor de tal poder como ele é exercido.

Quanto à forma de Governo de um Estado, leciona o Direito Constitucional que:

Pelo modo de organização política do Estado, existem duas formas básicas de governo: monarquia e república. Quanto à monarquia, palavra de origem grega (monarchia), governo deu um só, caracteriza-se pela vitalicidade, hereditariedade e irresponsabilidade do Chefe de Estado. O monarca governa enquanto vive. A escolha é feita dentro da linha de sucessão dinástica e o Rei não tem responsabilidade política. A monarquia pode ser absoluta ou relativa. $\mathrm{Na}$ absoluta, todo o poder está concentrado nas mãos de uma só pessoa, que o exerce de forma ilimitada, sem qualquer controle. Possui poderes ilimitados tanto para fazer as leis como para aplicálas. $\mathrm{Na}$ monarquia limitada ou constitucional, o poder do soberano é delimitado pela constituição. Exemplos: BrasilImpério, Reino Unido da Grã-Bretanha, Espanha e Japão. Quanto à República, palavra de origem latina, res publica, coisa pública, caracteriza-se pela eletividade, temporiedade e responsabilidade do Chefe de Estado. São feitas eleições periódicas para a escolha deste, que deve prestar conta de seus atos para o povo que o elegeu ou para um órgão de representação popular. ${ }^{83}$

Quanto às formas de Governo atuais ou o modo de organização política do Estado, ou seja, se Monarquia ou República, a que mais se aproxima da forma de Governo da

\footnotetext{
82 SILVA, José Afonso da. Curso de Directo Constitucional Positivo. São Paulo: Malheiros, 2000. p. 106.

${ }^{83}$ PINHO, Rodrigo César Rebello. Teoria geral da Constituição e direitos fundamentais. São Paulo: Saraiva, 2000. p. 4. Cf. também SILVA, José Afonso da. op cit., p. 106.
} 
Igreja é a Monarquia. À "coletividade política” da Igreja não se pode aplicar "o designativo de res publica, no seu sentido originário da coisa pública, ou seja, coisa do povo e para o povo", ${ }^{84}$ no sentido dado por Cícero, ${ }^{85}$ ou seja, das diversas coisas da sociedade pública, às quais todos têm igual direito, pois se na forma republicana de governo a questão essencial consiste na legitimidade da mesma, que deve derivar de eleições populares ${ }^{86}$ na coletividade ou na Sociedade da Igreja, a legitimidade dos seus governantes, isto é, dos detentores da Suprema Autoridade na mesma, de modo algum passa pelo crivo de eleições populares, mas sim através da provisão canônica ou da missão canônica ${ }^{87}$ que nada mais é que um ato de hierarquia que confere poder e o exercício daquele determinado ofício. A provisão canônica de um ofício eclesiástico é o conjunto de atos mediante os quais: (1) designa-se a pessoa que haverá de desempenhá-lo; (2) concede-se a mesma, mediante ato da autoridade legitima, o titulo que justificará o exercício; (3) entrega-se a mesma a posse do ofício (investitura) ${ }^{88}$ É pela provisão canônica, então, que ocorre o conferimento do ofício eclesiástico: “(...) qualquer múns conferido de maneira estável para um fim espiritual" ${ }^{89}$ Tal conferimento pode acontecer de quatro modos, dependendo da pessoa que vai desempenhar o ofício:

- Colação livre: é a designação direta pela própria autoridade;

- Apresentação: é a designação de um ou vários candidatos (por exemplo, uma lista tríplice) por uma pessoa ou um corpo colegiado diferente da autoridade conferente;

- Eleição: é a designação feita mediante escrutínio secreto, por um corpo colegiado, de uma pessoa, que precisa ou-não de confirmação, mas que reúne os requisitos canônicos para desempenhar o oficio. No caso da eleição do Papa, não é necessária a confirmação, bastando apenas a aceitação do eleito;

- Postulação: é igualmente a designação feita por escriturário, as de uma pessoa que não reúne todos os requisitos canônicos, precisando, por isso, de uma dispensa da autoridade. ${ }^{90}$

\footnotetext{
${ }^{84}$ Cf. SILVA, José Afonso da. Curso de Directo Constitucional Positivo. São Paulo: Malheiros, 2000. p. 106.

${ }^{85}$ CÍCERO. Da República. III, §§ XXI e XXII, citado por Cf. SILVA, José Afonso da. op cit., p. 106.

${ }^{86}$ Cf. SILVA, José Afonso da. op cit., p. 107.

${ }^{87}$ Cân.. 146, CIC.

88 Jesus Hortal, comentando o Cân.. 146 do Código de Direito Canônico de 1983, op. cit., p. 65.

${ }^{89}$ Decreto Presbyterorum Ordinis, 20b,

90 Jesus Hortal, comentado o Cân.. 146 do Código de Direito Canônico de 1983, op. cit., p. 65.
} 
Através desses quatro modos, todos os ofícios eclesiásticos são preenchidos. No caso dos detentores da Suprema Autoridade da Igreja (Papa e bispos), que nos interessa nesse nosso artigo, o conferimento daquele múnus se dá da seguinte forma: o Papa por eleição (Colégio dos Cardeais) e os bispos por apresentação (Lista Tríplice ou rosa três nomes). Este último revela propriamente dito o aspecto aristocrático da forma de governo da Igreja, no sentido que somente ao Papa cabe escolhê-los, o que torna os bispos um pequeno grupo que governa em relação ao resto dos fiéis. Diga-se, ainda, que o modo do conferimento do Oficio Petrino verifica-se por eleição, embora lembre, de algum modo, o critério eletivo dos Estados Constitucionais, talvez pelo seu escrutínio secreto. Todavia, trata-se de uma verdadeira reserva jurídica do Colégio dos Cardeais desde o sáculo IX; portanto, o escrutínio secreto vige na Igreja há sete séculos, antes do surgimento dos Estados Democráticos (1648 - Vestfália).

Francesco D’Ostillo entende que o Poder Supremo da Igreja é uma Monarquia Constitucional, Eletiva, com Elementos Democráticos e Aristocráticos..$^{91}$ Como já dissemos na Introdução, entendemos que tal afirmação do referido autor constitua a abordagem correta da questão da Forma de Governo da Igreja Católica. Embora tenha falado por parte do mesmo uma explicação mais demorada quanto aos elementos que compõem essa definição básica, a seguir, portanto, procuraremos as possíveis razões explicativas de tal asserção do Autor, aprofundando-a e completando-a com outros atributos que reputamos coerentes com a mesma, não sem antes ratificar tal entendimento de Francesco D'Ostilio, citando o pensamento, claríssimo, de Francisco Suarez (XVI), que por si só já desbanca qualquer dúvida em questão:

O Poder Universal - Supremo - da Igreja em si mesmo não reside no conjunto ou em cada um dos fiéis, mas sim em um único homem ${ }^{92}$ - ou seja, o Papa -, o que vale dizer que a forma de governo da Igreja é Monárquica. ${ }^{93}$

Comecemos pelo primeiro elemento da fórmula adotada por Francesco D’Ostilio, a saber: Monarquia.

A forma de governo da Igreja é uma monarquia inicialmente pelo modo em que o Princípio Petrino foi instituído por Cristo, como cabeça do Colégio Apostólico,

\footnotetext{
${ }^{91}$ D’OSTILIO, F. Prontuario del Codice di Diritto Canônico. Città del Vaticano: Libreria Editrice Vaticano, 1994. p. 176.

$92 \mathrm{O}$ grifo é nosso e de Alfred Verdross.

93 O grifo é nosso e de Alfred Verdross. VERDROSS, Alfred. Fondement du Droit International. Recueil des Cours, v. 1, 1927, p. 254, citando SUAREZ, Francisco. De triplici virtute theological. IX, sect. 7, n. 7: "Potestas universalis in totan Ecclesiam per se no residet in tota aliqua hominum congregatione aut multitudine sed in uno homine, quod est dicere, Ecclesiae regimen esse Monarchium”.
} 
e sucessivamente como cabeça do Colégio Episcopal, porque, apesar de ambos gozarem igualmente daquele poder fundamental, é a Pedro que foi dada a plenitude pastoral e jurídica - e que, mesmo sem o Colégio Episcopal reunido, o Papa é sempre a única Suprema Autoridade da Igreja. ${ }^{94}$

Em segundo lugar, a Tradição Católica e o Princípio da Fésempre entenderam Pedro e os Apóstolos enquanto os Príncipes da Igreja e aquele primeiro como Príncipe dos Apóstolos. Conseqüentemente, os seus sucessores, respectivamente, o Papa e os bispos, também herdam a mesma dignidade. Aliás, tal dignidade deriva, essencialmente, do fato do Messias (o Cristo) ser o Príncipe da Paz. ${ }^{95}$ Também, a práxis histórica internacional das nações sempre reconheceu aquela mesma realiza aos detentores do Poder Supremo da Igreja, isto é, o Papa sempre foi visto como verdadeiro monarca, em sentido estrito, da Igreja, e os bispos enquanto os príncipes da mesma. A forma de organização política do Papado, bem como o de toda a sociedade internacional da Idade Média, era monárquicoaristocrática. ${ }^{96} \mathrm{E}$ até as reformas realizadas pelo Papa Paulo VI nos exércitos do Vaticano, um deles, o que foi abolido, ostentava em seu nome a qualidade de "Guarda Real Pontifícia" (hoje restou apenas a Guarda Suíça). O mesmo se pode afirmar da Escola Diplomática da Santa Sé, que antes se chamava Pontifícia. Estas mudanças refletem um esforço das instituições eclesiásticas da Igreja em se adaptarem ao espírito do Concílio Vaticano II (1963-1965), baseado mais na dimensão pastoral do serviço na Igreja. Portanto, tratou-se de um esforço da Igreja de destacar mais a realeza da dignidade do batismo e ressaltar a igualdade de todos os filhos de Deus, enquanto batizados, em detrimento, portanto, da diferença por estirpe ou condição social, vale dizer, a aristocrática. Em outras palavras, o Concílio Vaticano II levou a Igreja a demonstrar menos, muito menos, o seu fausto aristocrático de todos os séculos passados, para mostrar-se mais próxima e servidora de todos os homens. Porém, se a Igreja atualizou a sua antiga roupagem aristocrática, o Papa e os Bispos, se bem que muito mais despojados e acessíveis, nada perderam no seu ser mais íntimo aquela dignidade real a eles, justamente, sempre reputada e herdade dos Apóstolos e do próprio Senhor Jesus.

\footnotetext{
${ }^{94}$ HORTAL, Jesus. op. cit., Jesus Hortal, comentando o Cân.. 336, afirma o seguinte: "Já durante o Concílio, mas especialmente depois, tem-se discutido sobre as relações entre o Colégio Episcopal e a sua cabeça: tratase de um ou de dois sujeitos diferentes? Nem o Concílio, nem o Código dirimem a questão. Inclinamo-nos pela opinião de que se trata de dois sujeitos inadequadamente distintos e não apenas de um sujeito (o Colégio Episcopal) que atuaria de dois modos diversos (pessoalmente, através da cabeça, e colegialmente)".

${ }_{95} \mathrm{Zac}, 9,10$.

${ }^{96}$ VERDROSS, Alfred. op. cit., p. 254: “(...) Cette nuvelle organization se distingue del'autre por le fait que la societé internationale du moyen Âge abatí - comme nous l'avous vu 1 une forme monarchique (aristocratique) tandis que la cummunalté internationale moderne prit nassance sous une forme démocratique".
} 
O segundo aspecto da fórmula de Francesco D’Ostilio é o Constitucional.

$\mathrm{O}$ aspecto da constitucionalidade da monarquia da Igreja, muito embora a Igreja não possua uma Carta Constitucional propriamente dita, revela-se pelo fato de seus poderes estarem determinados no Código de Direito Canônico.

A forma de governo da Igreja, além de ser Monárquica, é constitucional, se bem que sui generis. Embora Francesco D'Ostilio não afirme isso, entendemos que a Monarquia Papal é, sim, constitucional, mas de uma forma muito especial, quase que simbólica nesse sentido, isto é, o Direito Canônico vigente liga o Papa, legitimamente, a uma serie de condições e modos de procedimentos e ao respeito por direitos, sem que por isso diminua o seu poder de jurisdição suprema; ${ }^{97}$ vale dizer, o Papa exerce a sua Função Petrina, segundo o Código de Direito Canônico, mas é o próprio Código a afirmá-lo como Suprema Autoridade da Igreja. Em outras palavras, é como se o legislador canônico quisesse afirmar que, apesar das limitações jurídicas que ele coloca ao poder de governo do Papa, a sua prerrogativa, enquanto Suprema Autoridade da Igreja, fica totalmente preservada e acima das mencionadas limitações jurídicas, embora dentro das mesmas:

Cân.. 331 - O Bispo da Igreja de Roma, no qual perdura o múnus concedido pelo Senhor singularmente a Pedro, primeiro dos Apóstolos, para ser transmitido aos seus sucessores, é a cabeça do Colégio dos Bispos, Vigário de Cristo e, aqui na terra, Pastor da Igreja Universal; ele, pois, em virtude de seu múnus, tem na Igreja o poder ordinário, supremo, pleno, imediato e universal, que pode sempre exercer livremente.

Cân.. 333, $\S 1^{\circ}-O$ Romano Pontífice, em virtude de seu múnus, não-só tem poder sobre a Igreja Universal, mas obtém ainda a primazia do poder ordinário sobre todas as Igrejas particulares e entidades que as congregam, pelo qual é, ao mesmo tempo, reforçado e defendido o poder próprio, ordinário e imediato que o Bispo tem sobre as Igrejas particulares confiadas a seu cuidado.

$\S 2^{\circ}$ - O Romano Pontífice, no desempenho do múnus de Pastor Supremo da Igreja, está sempre unido em comunhão com os outros Bispos e até com toda a Igreja; entretanto, ele tem o direito de determinar, de acordo com as necessidades da Igreja, o modo pessoal ou colegial de exercer esse oficio.

$\S 3^{\circ}$ - Contra uma sentença ou decreto do Romano Pontífice não há apelação.

\footnotetext{
${ }^{97}$ HEIMER, H. Bases para um Código Constitucional da Igreja. Concilium, n. 6, p. 55-64, jun. 1967. p. 57.
} 
Nesse sentido, se “(...) as constituições do Estado são muitas vezes promulgadas para limitar o poder absoluto do monarca, deve aqui se acentuar que o pleno poder do Papa não pode ser mais energicamente limitado pelo Código de Direito Canônico do que já o é por direito divino". ${ }^{98}$

Cabe, aqui, um parêntese para explicar os seguintes conceitos: lex positiva divina, ou lex aeterna: Direito Divino; lex naturalis: lei natural; jus naturale: Direito Natural; lex positiva humana: Direito Positivo humano.

A lex positiva divina, ou lex aeterna, é a lei editada por Deus na Sagrada Escritura; exprime a idéia do governo divino do universo. Segundo Santo Tomás, a lei eterna não é senão "a razão sábia de Deus enquanto ela dirige cada ação e cada movimento".99

O homem participa de uma maneira eminente da lei eterna, na sua condição de ser dotado de razão; dessa forma, nasce o conceito de lex naturalis: lei natural é, portanto, aquela "participação da criatura racional na lei eterna". ${ }^{100}$ Vale dizer, trata-se da própria lei eterna impressa no coração do homem. A lei eterna, por sua vez, compreende a moral e o Direito Natural, segundo ela rege as ações humanas em vista do fim último do homem ou de suas relações com os outros homens. O Direito Natural (jus naturale) é, afinal, aquela parte da lei natural que regula a vida social. É a partir da lei natural que deriva a lex positiva humana, por via de conclusão ou de determinação de seus princípios. ${ }^{101}$ Portanto,

(...) é de direito natural tudo aquilo que à luz da razão natural
aparece para todos claramente justa, e injusta o contrário,
como, por exemplo, não roubar, não condenar à morte o
inocente e não fazer aquilo que não gostaria que se fizesse
para si mesmo."
"É igualmente de direito natural tudo aquilo que se deduza
por via de conseqüencia manifesta de princípios evidentes
por si mesmos. ${ }^{12}$

Subordinação do Direito Positivo humano ao Direito Natural:

O que é o justo pela própria natureza da coisa é de direito natural. $O$ que é justo pela força da lei ou em virtude da

\footnotetext{
${ }_{98}$ HEIMER, H. Bases para um Código Constitucional da Igreja. Concilium, n. 6, p. 55-64, jun. 1967. p. 57.

99 Sum. Theol., $\mathrm{I}^{\mathrm{a}}-\mathrm{I}^{\text {ae }}$, q. 93, a. 1).

${ }^{100}$ Id. Ibid., q. 91, a. 2).

${ }^{101}$ TRUYOL SERRA, Antonio. Lês principes du Droit Public chez Francisco de Vitoria. Madrid: Ediciones Cultura Hispanica, 1946. p. 25.

${ }^{102}$ In. II ${ }^{\mathrm{am}}-\mathrm{II}^{\mathrm{ae}}$ de justitia, q. 57, a. 2, 4: Id. Ibid., op. cit., p. 25.
} 
lei de uma convenção privada, e não pela natureza da mesma coisa, é de direito positivo. Direito Natural e direito necessário são uma mesma coisa; isto é, o direito natural é aquele que é necessário e que, conseqüentemente, não depende de alguma vontade. Aquele direito que, por sua vez, depende da vontade e da aprovação dos homens chama-se direito positivo.

Uma lei humana que se oponha sem motivo ao direito natural e divino será desumana e contrária à razão, e não teria força de lei..$^{103}$

Assim, retomando à questão do aspecto constitucional sui generis da forma de governo da Igreja Católica, pode-se afirmar que, ao mesmo tempo em que o poder do Papa é limitado pelo Código de Direito Canônico, este também o reconhece como Autoridade Suprema, quer dizer, que está acima até do próprio Código, ou seja, em sentido amplo, tal autoridade só é realmente limitada pelo Direito Divino que o instituiu. Todavia, o direito divino já constitui, por outro lado, a limitação mais estrema do Poder Supremo do Papa. E relembrando o núcleo do decreto de instituição do Poder Supremo da Igreja pelo Senhor Jesus, ela se concentra em duas idéias fundamentais: "atar e desatar" e "poder das chaves", o que diz respeito ao tipo de poder que está sendo transmitido aos Apóstolos, vale dizer, trata-se de um poder soberano, isto é, à primeira vista sem limites: "tudo o que vós ligardes...". Contudo, trata-se de um poder limitado, porque o poder de governo do Papa sobre a Igreja é, primordialmente, um poder Vigário, ou seja, é exercido em nome do seu fundador, Nosso Senhor Jesus Cristo. E se é um poder Vigário, logo não é originário do Papa. Depois, tal poder de governo do Papa é limitado pelas Sagradas Escrituras, pelo Evangelho, por tudo aquilo que representa o patrimônio autêntico da fé católica e apostólica: Tradição, Magistério, etc. Existe, contudo, por outro lado, uma outra limitação inafastável à Suprema Autoridade do Papa, a saber: aquela representada pelo Direito Natural (direito de defesa, da honra, da boa fama, etc.). Vale dizer que o Papa tem sempre que respeitar os limites impostos pelo próprio Direito Natural, através do seu princípio base, ou seja, do ius suum ou o justo, objeto de justiça e exigência moral do homem de ser reconhecido como sujeito e de reconhecer enquanto tal o seu semelhante. ${ }^{104} \mathrm{E}$ nenhuma autoridade humana está dispensada de observar tal princípio essencial do Direito Natural, muito menos o Papa.

\footnotetext{
${ }^{103}$ In II ${ }^{\mathrm{am}}-$ II $^{\mathrm{ae}}$ de justitia, q. 57, a. 2, 4: TRUYOL SERRA, Antonio. Lês principes du Droit Public chez Francisco de Vitoria. Madrid: Ediciones Cultura Hispanica, 1946. p. 26.

${ }^{104}$ In II $^{\mathrm{am}}-$ II $^{\text {ae }}$ de justitita, q. 57, a. 2, 4: Id. Ibid., p. 26.
} 
Em outras palavras, trata-se de uma monarquia constitucional sui generis; porque, ao mesmo tempo em que o Poder Supremo da Igreja efetivamente é delimitado pelo Direito Canônico; este, todavia, declara explicitamente que tal poder está acima dele próprio, lançando-o, então, para os seus limites mais elevados, ou seja, o Direito Divino ou a Vontade Divina que o colocou de pé. E esta, como vimos, não colocou limite algum ao exercício de tal poder, dando a impressão que fosse um poder absoluto. Mas absoluto, nem ilimitado, tal poder não é, porque é limitado, implicitamente, ${ }^{105}$ pelo Direito Natural.

Em síntese, o Poder Supremo do Papa sobre a Igreja é constitucional sui generis, porque, embora possa parecer absoluto e ilimitado quanto a sua instituição divina, sofre a limitação, por um lado, do Direito divino (vicariedade, evangelho, patrimônio de fé, etc.), pelo outro, do Direito Natural, na sua valência mais exigente, ou seja, do justo natural (ius suum) como realização da justiça e do Direito Positivo Canônico e, por outro lado, pelo Código de Direito Canônico.

O terceiro elemento da fórmula de Francesco D’Ostilio é o aspecto eletivo da Monarquia Papal. ${ }^{106 / 107}$

Assim, depois de madura reflexão, cheguei à determinação de estabelecer que a única forma pela qual os eleitores podem manifestar os seus votos para a eleição do Romano Pontifice é o escrutínio secreto, efetuado segundo as normas mais à frente indicadas. ${ }^{108}$

Eis aqui a fundamentação canônica propriamente dita do caráter eletivo do Papa, constitucionalmente afirmado pela Suprema Autoridade Papal, através da mencionada Constituição Apostólica Universi Dominici Gregis. Logo, este caráter eletivo do Papa torna-se, também, designativo da Monarquia Papal, ou seja, Monarquia Eletiva.

- O Papa é escolhido pelos membros do Colégio de Cardeais com menos de 80 anos de idade, por ocasião da convocação do Conclave. ${ }^{109}$

- Na forma de Conclave (um lugar fechado com chaves). Note-se que a primeira eleição feita em forma de Conclave foi na cidade italiana de Perúgia, no ano

\footnotetext{
${ }^{105}$ Porque o Direito Natural é a própria lei positiva divina.

${ }^{106}$ Trata-se de reserva jurídica do COLÉGIO de Cardeais que vem desde o século IX.

${ }^{107}$ Motu Próprio Ingravescentem Aetatem, II, 2; AAS 62 (1970), p. 811; Constituição Apostólica Universi Dominici Gregis, op. cit., p. 305-342, Cidade do Vaticano: Libreria Editrice Vaticano, 1, 1996. Para aprofundamento, consulte: BARBOSA JÚNIOR, Tiago Wenceslau. A eleição do Romano Pontífice segundo a Constituição Apostólica Universi Dominici Gregis, promulgada pelo Santo Padre João Paulo II a 22 de fevereiro de 1996. Revista de Cultura Teológica, São Paulo, dez. 2004. p. 139.

${ }^{108}$ PAULO VI. Constituição Apostólica Universi Dominici Gregis. op. cit., p. 313.

${ }^{109}$ A rigor, o eleito pode ser de fora do Conclave. Id. Ibid., p. 321.
} 
de 1216, onde foi eleito o Papa Inocêncio III. A inovação nessa prática milenar consiste no fato de que, de agora em diante, este (o Conclave) deve ser feito dentro dos muros do Estado da Cidade do Vaticano - o que, na maioria das vezes, não foi possível no passado - e a eleição propriamente dita deverá ser feita dentro do recinto da Capela Sistina, do Palácio Apostólico do Vaticano: ${ }^{110}$

(...) Disponho que a eleição continue a desenvolver-se na Capela Sistina, onde tudo concorre para avivar a consciência da presença de Deus, diante do que ela deverá cada um apresentar-se um dia para ser julgado. ${ }^{111}$

Apresenta o critério dos dois-terços para a validade da mesma. ${ }^{112}$

Trata-se, então, de uma eleição por votação secreta.

- Se o eleito já não for bispo, após a aceitação, deverá receber imediatamente o caráter episcopal. ${ }^{113}$

\begin{abstract}
Aqui, ainda que de modo indireto, contempla-se a possibilidade de que o escolhido não seja um dos cardeaiseleitores, mas sim alguém de fora do conclave, mas entendo que nunca poderia ser um leigo, pois o leigo não está cingido com a ordem episcopal; e pelo menos sacerdote, uma vez que o eleito tornar-se-á Bispo de Roma e, por conseguinte, Pastor Supremo da Igreja Universal e, logo, trata-se de uma função eminente episcopal. O Papa só é Papa porque é Bispo de Roma. Esta questão, todavia, não é pacifica. ${ }^{114}$
\end{abstract}

- A investidura do eleito ocorre simpliciter com a sua aceitação ${ }^{115}$ (...) e exercerá as suas funções de modo vitalício, vale dizer, até morrer, salvo as hipóteses de cessão canônica do Código. ${ }^{116}$

O Código de Direito Canônico, através do Cân. 332, § $2^{\circ}$, contempla a possibilidade de renúncia do Romano Pontífice, dizendo:

Se acontecer que o Romano Pontífice renuncie a seu múnus, para a validade se requer que a renúncia seja livremente

\footnotetext{
${ }^{110}$ BARBOSA JÚNIOR, Tiago Wenceslau. A eleição do Romano Pontífice segundo a Constituição Apostólica Universi Dominici Gregis, promulgada pelo Santo Padre João Pauylo II a 22 de fevereiro de 1996. Revista de Cultura Teológica, São Paulo, dez. 2004. p. 139.

${ }^{111}$ PAULO VI. Constituição Apostólica Universi Dominici Gregis, cit., p. 327.

112 Id. Ibid., p. 331.

${ }^{113}$ Id. Ibid., p. 341.

${ }^{114}$ BARBOSA JÚNIOR, Tiago Wenceslau. op. cit., p. 159.

${ }^{115}$ PAULO VI. Constituição Apostólica Universi Dominici Gregis, cit., p. 341.

${ }^{116}$ Id. Ibid., p. 341.
} 
feita e devidamente manifestada, mas não que seja aceita por alguém.

Este raciocínio do Cânon se justifica, porque acima do Papa não existe uma outra autoridade na Igreja a quem ele possa apresentar a sua renúncia, uma vez que ele é a única e insuperável Suprema Autoridade de toda a Igreja.

A doutrina canônica ainda entende que o poder Papal cessa nas seguintes circunstâncias: morte; demência perpétua; heresia formal (negação pertinaz, após a recepção do batismo, de qualquer verdade que se deva crer com fé divina e católica ou dúvida pertinaz a respeito dela - Cân. 751, CIC); apostasia (repúdio total da fé cristã) - Cân. 751. ${ }^{117}$

O elemento que agora vamos contemplar está na fórmula de Francesco D'Ostilio implicitamente, a saber: vitaliciedade.

- A investidura do eleito ocorre simpliciter com a sua aceitação ${ }^{118}$

(...) e exercerá as suas funções de modo vitalício, vale dizer, até morrer, salvo as hipóteses de cessação canônica do Código. ${ }^{119}$

A Monarquia Papal, além de ser Constitucional sui generis e eletiva, é também caracterizada pelo aspecto da vitaliciedade, vale dizer, uma vez eleito pelo Conclave e devidamente aceito pelo mesmo tal escolha, o Papa governa enquanto viver, como já o disse, salvo as hipóteses de cessação daquele ofício.

Também o aspecto da irresponsabilidade da Monarquia Papal é extraído de modo conseqüencial da fórmula de Francesco D’Ostilio.

É uma Monarquia Irresponsável, porque o Papa não tem responsabilidade política, isto é, não deve dar explicações aos fieis ou a qualquer órgão eclesiástico sobre os motivos pelos quais adotou certa orientação política. Isso porque o Papa reúne em sua pessoa as figuras de chefe da Igreja Católica, chefe de Estado e chefe de Governo, uma vez que o Sumo Pontífice não tem Parlamento.

Cân. 333, § $2^{\text {o: }}$

O Romano Pontífice, no desempenho do múnus de Pastor Supremo, está sempre unido em comunhão com os outros Bispos e até com toda a Igreja; entretanto, ele tem o direito de determinar, de acordo com as necessidades da Igreja, o modo pessoal ou colegial de exercer esse ofício.

\footnotetext{
${ }^{117}$ GHIRLANDA, Gianfranco. Il diritto nel mistero della Chiesa. Roma, 1985/86. p. 127.

${ }^{118}$ PAULO VI. Constituição Apostólica Universi Dominici Gregis, cit., p. 341.

${ }^{119}$ Id. Ibid., p. 341.
} 
Por último, a fórmula de Francesco D’Ostilio é dotada dos seguintes elementos: o democrático e o aristocrático.

A Suprema Autoridade da Igreja possui elementos democráticos no sentido em que todos os seus fiéis, ou seja, todos os batizados, sem qualquer discriminação ${ }^{120}$ podem aceder aos ofícios eclesiásticos. ${ }^{121}$

O Poder Supremo da Igreja é dotado, também, de elementos aristocráticos, vale dizer, cabe ao Papa nomear os bispos como pastores, enquanto um pequeno grupo em relação aos fiéis, os quais são insuprimíveis. ${ }^{122}$

Em síntese, a definição da forma de governo da Igreja, formulada por Francesco D’Ostilio, ficaria do seguinte modo, considerando os acréscimos e especificações que fizemos: Monarquia Constitucional sui generis, eletiva, vitalícia, irresponsável, com elementos democráticos e aristocráticos.

7. A Igreja Católica: Regime Político de Governo, segundo o Direito Constitucional

De acordo com o grau de respeito à vontade do povo nas decisões estatais, os regimes políticos podem ser classificados em democráticos e não-democráticos. Democracia, palavra de origem grega, demos - povo e arché - governo, governo do povo, é o regime político em que todo o poder emana da vontade popular. Na clássica definição, é o governo do povo, pelo povo e para o povo. O regime democrático pode ser exercido: a) de forma direta; b) por representantes; ou c) combinando ambos os critérios. ${ }^{123}$

$\mathrm{Na}$ democracia direta as decisões são tomadas pelo próprio povo em assembléias. Exemplos: as antigas cidades gregas, em que os cidadãos julgavam e tomavam decisões políticas importantes em assembléias. Sobrevive esse sistema de democracia direta ainda em alguns cantões suíços de pequenas populações. ${ }^{124}$

Na democracia representativa as decisões são tomadas por representantes livremente escolhidos pelo povo. Em grandes países, é absolutamente impossível pretender reunir toda a população em uma praça para a obtenção de uma decisão única. ${ }^{125}$

\footnotetext{
${ }^{120}$ A não ser as discriminações feitas propriamente pelo Direito Canônico, segundo as exigências e a natureza de cada ofício, por exemplo, ofícios que só quem tem o Sacramento da Ordem pode ocupar, etc.

${ }^{121}$ D’OSTILIO, Francesco. op. cit., p. 176.

${ }^{122}$ Id. Ibid., p. 176.

${ }^{123}$ PINHO, Rodrigo César Rebello. op. cit., p. 6-7.

${ }^{124}$ Id. Ibid., p. 6-7.

${ }^{125}$ Id. Ibid., p. 6-7.
} 
Na democracia semidireta combinam-se ambas as formas de democracia; é a democracia representativa, com alguns instrumentos de participação direta do povo na formação da vontade nacional. É o regime político adotado pela Constituição brasileira, de 1988 , em seu art. $1^{\text {o }}$, parágrafo único: "Todo o poder emana do povo, que o exerce pelo meio de representantes eleitos ou diretamente, nos termos desta Constituição". A Carta Magna admite como formas de participação direta do povo o plebiscito, a oferenda e a iniciativa popular (art. 14, I, II e III). ${ }^{126}$

Regimes não-democráticos são aqueles que sustentam diversos graus de autoritarismo, conforme a maior ou menor participação popular na formação da vontade nacional: regimes autoritários, ditatoriais e totalitários. A característica comum desses regimes é a não-prevalência da vontade popular na formação do governo. ${ }^{127}$

Doutrina do Direito Internacional Público sobre o conceito de Estado

Por sua vez, a Doutrina do Direito Internacional Público sobre o conceito de Estado ensina o quanto se segue.

O Estado é uma forma de organização da sociedade, que emergiu, de maneira espontânea, no momento histórico em que o poder de um governante se tornou exclusivo sobre um território, passando pessoas e coisas a serem submetidas a seu poder jurisdicional, em virtude de dois vínculos possíveis, concomitantes ou exclusivos: uma simples situação de nele estar e por possuírem sua nacionalidade. A realidade jurídica e política que é o Estado, nascido no século XVI, traria posterior desenvolvimento na história das instituições e fatos sociais, ao mesmo tempo em que se estabeleciam limites à abrangência territorial e pessoal de suas competências. Existe uma definição formal de Estado na Convenção Panamericana de Montevidéu, de 1993, sobre Direito e Deveres dos Estados (no Brasil promulgada pelo Decreto n. 1.570, de 13/04/1937), assim redigido:

O Estado, como pessoa de Direito Internacional, deve reunir os seguintes requisitos: a) população permanente; b) território determinado; c) Governo; e d) a capacidade de entrar em relações com os demais Estados. ${ }^{128}$

O Estado da Cidade do Vaticano constitui, por força do Tratado de Latão, de 1929, entre a Santa Sé e a Itália, a base material ou territorial para albergar a soberania espiritual do Papa ou da Suprema Autoridade da Igreja (Santa Sé), assegurando-lhe, assim,

\footnotetext{
${ }^{126}$ PINHO, Rodrigo César Rebello. Teoria geral da Constituição e direitos fundamentais. São Paulo: Saraiva, 2000. p. 6-7.

${ }^{127}$ Id. Ibid., p. 6-7.

${ }^{128}$ SOARES, Guido Fernando Silva. Curso de Direito Internacional Público. São Paulo: Atlas, 2002. p. 143144.
} 
de modo estável, independência absoluta e visível no campo internacional. Apesar de seus 42 hectares de superfície, ou seja, menos de meio quilômetro quadrado, e da sua diminuta população, o Estado da Cidade do Vaticano é, em todo caso, um Estado ao qual não falta, de acordo com os termos do referido Tratado, nenhum dos caracteres formais do Estado soberano e sobre o qual o Papa exerce plena soberania. O Papa, então, satisfaz plenamente o requisito de governo do Estado soberano, porque concentra em sua pessoa as qualidades de chefe de Estado, chefe de Governo, além de chefe da Igreja Católica, com plena capacidade de legação passiva e ativa: receber e enviar embaixadores.

Os conceitos mais elementares, forma de governo, regime político, tomados pelo Direito Constitucional à Teoria Geral dos Estados, não servem, contudo, para determinar a forma e o regime de governo da Igreja. Isto porque, quando o Direito Constitucional ou a Teoria Geral do Estado fala de regime político de um Estado, referese aos regimes políticos que, por sua vez, podem ser democráticos e não-democráticos, dependendo do grau de respeito à vontade do povo nas decisões estatais. Em outras palavras, os regimes políticos são considerados democráticos ou-não, segundo o grau de prevalência do princípio da maioria democrática nas decisões governamentais. Nesse sentido, a idéia de fundo de tal princípio é o povo, entendido como detentor de toda a soberania estatal.

Ora, como podemos ver ao longo do desenvolvimento do nosso artigo, a instituição do poder na Igreja não é de modo algum fundamentada no povo ou na vontade dos seus fiéis, mas, sim, na própria vontade do seu fundador, Jesus Cristo. É a Vontade Divina, portanto, o alicerce fundamental no qual repousa a origem do poder da Igreja. Assim sendo, o regime de governo da Igreja não pode ser democrático, nem tão pouco colegial, por causa da sua relação com o Colégio dos Bispos; muito menos é aristocrático, etc.

Em outras palavras, o poder na Igreja não pode assumir pensamentos fundamentais da soberania do povo, uma vez que não é do povo que ele parte, nem tampouco dos detentores da autoridade eclesiástica; no seu cerne mais autêntico, o ponto de partida do poder na Igreja é Cristo. A Igreja acha-se determinada pela natureza espiritual do poder comunicado por Cristo aos bispos, sacerdotes e diáconos, e não pela divisão de poderes de um moderno estado constitucional; a ordem das dignidades é proposta, em larga medida, pelo Direito Divino. ${ }^{129}$

\footnotetext{
${ }^{129}$ HEIMER, H. Bases para um Código Constitucional da Igreja. Concilium, n. 6, p. 55-64, jun. 1967. p. 56.
} 
Assim, não é possível, facilmente, aplicar princípios e formas democráticas à Igreja como, também, seria ilícito banir da Igreja todo o pensamento democrático. ${ }^{130}$

Portanto, se o poder na Igreja, bem como o seu exercício, não está de modo algum fundamentado na vontade dos fieis, logo não há como aplicar o conceito de regime de governo democrático ao regime de governo da Igreja. Contudo, a Igreja possui seu regime de governo no que pareceria diante dos atuais regimes de governo democráticos, como sendo atípico e imutável, porque, exatamente, não depende da vontade dos fiéis, ${ }^{131}$ mas, sim, da Vontade Divina, e imutável, porque aquilo que foi posto por Deus não pode ser tocado pelo homem eclesiástico.

$\mathrm{O}$ grau de respeito à vontade dos fiéis ou o modo em que ocorrem as relações intersubjetivas na Igreja (relação autoridade-súdito) se dá através do vínculo denominado de koinonia-communio, ou união eclesiástica, ${ }^{132}$ vale dizer, através dos seguintes aspectos:

- Comunhão com Cristo e com a Trindade (Pai, Filho e Espírito Santo) em referimento à Eucaristia;

- Comunhão Eclesial: que deriva da Comunhão com Cristo e com a Trindade. É o vínculo existente entre os batizados e as Igrejas, criado pelo Espírito Santo, na pluralidade dos dons hierárquicos e carismáticos e dos ministérios, com um referimento constitutivo à Eucaristia e que se manifesta na comunhão da vida, da fé, dos sacramentos, de caridade, de bens espirituais, de obras apostólicas e de doações, de modo tal que a variedade não prejudique a unidade;

- Comunhão Eclesiástica: possui a sua fonte e o seu centro em Cristo e vive entre as Igrejas Particulares (locais ou diocesanas) e contribui para a única celebração eucarística. Constitui a comunhão plena;

- Comunhão hierárquica: é o vínculo orgânico e estrutural, e não puramente espiritual, existe entre os bispos e a Cabeça do Colégio Episcopal e os membros do mesmo; entre os presbíteros e a Ordem dos Bispos; entre os diáconos e o bispo e o seu presbitério. É o elemento constitutivo da Comunhão Eclesiástica. Comunhão Hierárquica e Comunhão Eclesiástica são termos correlativos. O termo Comunhão Hierárquica indica, ao mesmo tempo, uma síntese entre a estrutura de comunhão e da missão da Igreja. ${ }^{133}$

\footnotetext{
${ }^{130}$ HEIMER, H. Bases para um Código Constitucional da Igreja. Concilium, n. 6, p. 55-64, jun. 1967. p. 56.

${ }^{131}$ D’OSTILIO, Francesco. op. cit., p. 176.

${ }^{132}$ GHIRLANDIA, Giancarlo. op. cit., p. 16-17.

${ }^{133}$ Id. Ibid, p. 16-17.
} 
Assim, o vínculo da koinonia-communio ou união eclesiástica refere-se tanto às relações entre os membros da própria hierarquia da Igreja (bispos, presbíteros e diáconos) (comunhão hierárquica), quanto às relações dos fiéis entre si e desses com os membros da hierarquia (relação Pastor-ovelha), baseadas na fé e na obediência doutrinal e disciplinar.

Portanto, quanto ao princípio democrático da maioria (vontade popular ou o grau de respeito à vontade do povo nas decisões estatais), A Suprema Autoridade da Igreja possui um Regime Político atípico e imutável; atípico, porque totalmente impar quanto aos atuais regimes políticos constitucionais de governo; imutável, porque foi estabelecido por Deus, através de Jesus Cristo. Quanto ao modo de organização política do Estado ou forma de governo, a Suprema Autoridade da Igreja é uma monarquia constitucional sui generis eletiva, vitalícia, e responsável, com elementos democráticos e aristocráticos.

\section{A Suprema Autoridade da Igreja Católica e a Santa Sé134}

A relação entre a Suprema Autoridade da Igreja e a Santa Sé consiste no fato de que esta última é o Centro do Governo da Igreja Católica, quer no plano nacional de cada Estado onde a Igreja Católica está presente, quer no plano internacional, ou seja, no plano das relações diplomáticas entre Estados. A Santa Sé, por sua vez, é constituída essencialmente pelo Ofício do Papa (Função Petrina), o que significa dizer que o titular, em sentido estrito, ${ }^{135}$ da Suprema Autoridade da Igreja Católica e que, portanto, personaliza a Santa Sé é o Papa. E seus direitos e prerrogativas decorrem precisamente por causa da sua soberania espiritual enquanto:

1. Cabeça do corpo eclesial (com seu tríplice poder de ensinar, santificar e governar); com o poder supremo, pleno, imediato e universal que lhe é próprio;

2. Soberano temporal do Estado da Cidade do Vaticano: chefe de Estado e chefe de Governo;

3. Patriarca do Ocidente, primaz da Itália, metropolita da Província romana e bispo de Roma;

\footnotetext{
${ }^{134}$ Queremos chamar a atenção para o fato de que a Suprema Autoridade da Igreja ou a Santa Sé são duas expressões com o mesmo significado, ou seja, significam a mesma realidade, vale dizer, o Papa ou, canonicamente falando, o Romano Pontífice.

${ }^{135}$ Como já vimos no item 5 - "que é o detentor do poder da Igreja e como se relaciona com seus fiéis", os beneficiários da Suprema Autoridade da Igreja são dois: o Papa e o Colégio dos Bispos. Porém, os papéis de cada um são diferentes, ainda que complementares.
} 
4. e com o conjunto dos órgãos que compõem o Oficio Primacial, tais como dicastérios, tribunais e oficiais romanos, no seu sentido amplo, ou seja, a Cúria Romana.

Destaca-se, aqui, então, o Papa enquanto chefe da Igreja Católica, com a qualidade de soberano espiritual com a abrangência global permanente, ou seja, a missão espiritual da Igreja Católica dura até o prometido retorno de Jesus Cristo.

É precisamente com base nesta soberania espiritual do Papa que se fundamenta as prerrogativas reconhecidas à Santa Sé, enquanto o poder soberano dotado de personalidade jurídica internacional própria e, principalmente, do direito de legação passivo e ativo para poder atingir os fins de sua atividade especial de cunho espiritual e fim religioso e humanitário.

Mas, além de ser o Chefe da Igreja Católica, a finalidade espiritual global da Igreja tornou necessário dotar o Papa também de uma soberania territorial, vale dizer, o Estado da Cidade do Vaticano, por ocasião do Tratado de Latrão, de 1929, entre a Santa Sé e a Itália. Em outras palavras, “(...) foi só necessidade de sedar base material à soberania espiritual do Papa, de se lhe conceder uma garantia de direito público internacional capaz de lhe assegurar a completa independência, que determinou a criação da soberania territorial da Santa Sé, ainda que uma área mui restrita". ${ }^{136}$

Dessa forma, o Papa, além de chefe da Igreja, tornou-se também chefe de Estado e chefe de Governo da Cidade do Vaticano. Assim a Santa Sé passou a gozar de independência política absoluta interna e, sobretudo, no campo internacional, necessária para a realização de sua missão de evangelização no mundo. Em outras palavras, a soberania territorial assegurou ao Papa a sua plena soberania espiritual. Convém, porém, não esquecer que a Personalidade Internacional do Soberano Pontífice não deriva do Tratado de Latrão. Ela lhe é muito anterior - o primeiro reconhecimento formal da mesma se deu com o Edito de Tessalônica, chamado Cunctos Populos, do imperador Teoclásio I, pelo qual o Estado romano reconhece formalmente a Personalidade Jurídica Internacional da Santa Sé e da Igreja Católica, em 380 d.C. ${ }^{137}$

\footnotetext{
${ }^{136}$ ACCIOLY, Hildebrando. Há 25 anos... a personalidade internacional do Papa. Separa da: A ordem, dez. 1930, p. 72. A Santa Sé e o Estado da Cidade do Vaticano são dois distintos sujeitos internacionais, embora possuam, também, uma intima relação de "união pessoal", vale dizer, o Papa é o Poder Supremo daqueles dois sujeitos internacionais. A personalidade jurídica internacional compete, porém, exclusivamente à Santa Sé, seja no plano interno - o próprio ordenamento canônico, seja no plano internacional - os tratados, concordatas. Portanto, o Bispo de Roma, além de chefe e supremo detentor do Oficio da Sé Apostólica, é também o soberano da Cidade do Vaticano.

${ }^{137}$ ACCIOLY, Hildebrando. op cit., p. 72. Para o aprofundamento, consulte a nossa tese de doutorado apresentada ao Departamento de Direito Internacional da Faculdade de Direito da Universidade de São Paulo, no dia 25 de outubro de 2004, intitulada “A Mediação da Santa Sé na Questão do Canal de Beagle”, p. 94-106.
} 
Logo, a Santa Sé vem a ser a suprema direção ou organismo supremo de direção de representação, tanto da Igreja Católica quanto do Estado da Cidade do Vaticano.

Conclusão

Quanto ao modo de organização política do Estado, a forma de governo da Igreja Católica é monárquica constitucional sui generis, Eletiva, vitalícia e irresponsável, com elementos aristocráticos e democráticos; e quanto ao grau de respeito à vontade do povo (fiéis) nas decisões estatais e papais, o seu regime de governo é atípico e imutável. Estas características quanto à forma e regime de governo da Igreja, apesar de serem impares em relação às estruturas constitucionais dos Estados Modernos, vêm perdurando na mesma já por 21 séculos, "o que demonstra com toda a clareza possível que tais meios de funcionamento da estrutura eclesiásticas são suficientes, vale dizer, são eficazes"; ${ }^{138}$ quer dizer, levam a Igreja a atingir a finalidade de sua alta missão espiritual. ${ }^{139}$ "Esta continuada constatação histórica não pode ser aduzida por nenhum dos Estados Soberanos existentes, naturalmente, quanto a sua longevidade". ${ }^{140}$

Finalmente, deve ser claramente acentuado, contra tendências positivistas - e democráticas - que a Igreja, desde o início teve a sua constituição - claro está, divina -, forma e regime de governo - que um código de Direito Constitucional (o Código de Direito Canônico) nada mais fez o que formular, exprimir e, mais exatamente, determinar -, ${ }^{141}$ embora não com terminologia e com os conceitos que adotamos agora.

Porém a margem de concentração do Poder Supremo pessoal do Papa, apesar dos limites dados pelo Direito Divino, pelo Direito Natural e pelo Direito Canônico, incomparavelmente maior do que o poder supremo da maior autoridade dos Estados constitucionais reservado ao Papa, enquanto "padrão jurídico"142 supremo da Igreja, apesar das limitações de poder já mencionadas, resta ainda incontestável, alem de

\footnotetext{
${ }^{138}$ LLANO CIFUENTES, Rafael. Curso de direito canônico. A Igreja e o Estado à luz do Vaticano II. São Paulo: Saraiva, 1971. p. 26.

${ }^{139}$ Isto não significa que tal modo de funcionamento da estrutura eclesiástica não contenha em si mesmo certas desvantagens, no plano interno pelo menos, próprias, talvez, de uma estrutura hierárquica, tais como: afunilamento, lentidão e forte pessoalidade das decisões dos membros da hierarquia, sobretudo as do Papa; uma forte tendência a uma política de influência; de favorecimento (nepotismo); tensão constante entre o Centro do Poder, ou seja, o Papa e a periferia da igreja ou a Igreja Católica nos Estados, etc.

${ }^{140}$ LLANO CIFUENTES, Rafael. op. cit., p. 26.

${ }^{141}$ HEIMER, H. op. cit., p. 56.

${ }^{142}$ DALLARI, Dalmo de Abreu. op. cit., p. 178.
} 
altaneiro na mesma. "O Estado Constitucional, no sentido de Estado enquadrado num sistema normativo fundamental, é uma criação moderna - século XVIII - e, em parte, sob influencia dos mesmos princípios", ${ }^{143}$ a saber: “(...) a afirmação da supremacia do indivíduo; a necessidade de limitação do poder dos governantes e a crença quase religiosa nas virtudes da razão, apoiando a busca da racionalização do poder". ${ }^{144} \mathrm{~A}$ idéia de Constituição ou do constitucionalismo traz no seu bojo o liberalismo político, ou seja, como "porto de convergência das lutas a favor dos direitos e da liberdade do indivíduo", ${ }^{45}$ em detrimento da limitação do poder absoluto dos governantes. Em outras palavras, " $a$ Constituição nasceu com a mística da limitação do poder e a afirmação das liberdades individuais (...)". ${ }^{146}$ É necessário lembrar, porém, que antes que o Estado Democrático surgisse em 1648, com o Tratado de Vestfália, a Igreja Católica já existia e era dotada com a forma e regime de governos, que acabamos de ver, há pelo menos 15 anos.

São Paulo, novembro de 2007.

Referências

ACCIOLY, Hildebrando. Há vinte e cinco anos... a personalidade internacional do Papa. Separada de: A Ordem, dez. 1930.

BARBOSA JÚNIOR, Tiago Wenceslau. A eleição do Romano Pontífice segundo a Constituição Apostólica Universi Dominici Gregis, promulgada pelo Santo Padre João Paulo II a 22 de fevereiro de 1996. Revista de Cultura Teológica, São Paulo, dez. 2004.

DALLARI, Dalmo de Abreu. Elementos de teoria geral do Estado. São Paulo: Saraiva, 1972.

D’OSTILIO, Francesco. Prontuário di diritto canonico. Città del Vaticano: Libreria Editrice Vaticano, 1994.

GHIRLANDA, Gianfranco. Il diritto nel mistero Della Chisa. Roma, 1985/86.

HEIMERI, H. Bases para um Código Constitucional da Igreja. Concilium, n. 6, p. 55-64, jun. 1967.

LACOSTE, Jean Yves. Diccionario crítico de teologia. São Paulo: Paulinas e Loyola, 2004.

\footnotetext{
${ }^{143}$ DALLARI, Dalmo de Abreu. Elementos de teoria geral do Estado. São Paulo: Saraiva, 1972. p. 174.

${ }^{144}$ Id. Ibid., p. 175.

${ }^{145}$ Id. Ibid., p. 176.

${ }^{146}$ Id. Ibid., p. 177.
} 
LLANO CIFUENTES, Rafael. Curso de direito canônico. A Igreja e o Estado à luz do Vaticano II. São Paulo: Saraiva, 1971.

PAULO VI. Alocução de 26.05.1966. . Alocução de 17.08.1968. . Constituição Apostólica Universi Dominici Gregis, (AAS, 88 [1996]) 22.02.1996. . Motu Proprio Ingravescentem Aetatem, II, 2 (AAS 62 [1970], 811).

PINHO, Rodrigo César. Rebello. Teoria geral da Constituição e direitos fundamentais. São Paulo: Saraiva, 2000 .

SILVA, José Afonso. Curso de direito constitucional privado. São Paulo: Malheiros, 2000.

SOARES, Guido Fernando Silva. Curso de direito internacional público. São Paulo: Atlas, 2002. v. 1.

SOUZA, Salmo Caetano de. A mediação da Santa Sé na questão do canal de Beagle. Tese (Doutorado) - Faculdade de Direito, Universidade de São Paulo, São Paulo. 2004.

SUAREZ, Francisco. De triplici virtute theological. IX, sect. 7, n. 7.

TRUYOL SERRA, Antonio. Lês príncipes du droit public chez Francisco de Vitoria. Madri: Ediciones Cultura Hispanica, 1946.

VERDROSS, A. fondement du droit international. Recueil des Cours, Leiden, v. 16, p. 247-323, 1927. 